\title{
The good migrant
}

The good migrant is placid. The good migrant accepts their place. The good migrant contributes. The good migrant pays their dues. The good migrant is domesticated. The good migrant is always happy to be here, forever grateful for the tolerance and begrudging acceptance of their hosts. They change their name because it was always too hard to pronounce. It made people feel awkward. They are happy to be given their marked and cramped space at the margins of the tolerant nation. The good migrant subjects themselves to the endless gaze, compromises their history to 'pass' and pose for the camera, in the thankless yet highly visible task to be 'included'.

On 17 October 2016 a small group of child refugees arrived in the English town of Croydon under a newly devised child resettlement scheme (commonly referred to at the time as the 'Dubs amendment'). Under this scheme the government had reluctantly agreed to allow initially 480 unaccompanied children, previously based in the informal settlement or 'Jungle' camp in Calais, the right to settle in the UK. ${ }^{1}$ Despite widespread initial support for the scheme (including from usually hostile right-wing tabloids), the fourteen minors stepping off coaches that day were doggedly hounded by the press. Almost immediately questions were raised as to whether these refugees were 'really children' As further doubt was spread over the next few days, journalists began referring to them as 'burly lads' (Greenhill et al. 2016). Attention was placed on their masculinity and bodied features of age such as 'crow feet', 'eye bags' and 'facial hair.' The Conservative MP David Davies 
tweeted that 'they don't look like "children" ... I hope British hospitality is not being abused' (quoted in McLaughlin 2018: 7).

Faced with what Elizabeth Brown (2011) calls 'unchildlike children', the Daily Mail became the first newspaper to publicly use facial recognition software to 'test' the refugees' ages (Wright and Drury 2017). The front covers of the following day's papers were full of photographic portraits of the children - now transformed into 'youth' or 'young men' - with their suspected, computer-generated ages showing them to be adults. Focus fell on the apparent risk these 'young men' would pose in British schools as a sexual threat to young girls (Wright and Drury 2017). Speaking in an interview on BBC Radio 4, Davies argued that these 'unchildlike' children should be subject to dental examinations and $\mathrm{X}$-rays to prove their age (BBC 2016). Warding off arguments that this would be unethical and a violent intervention, Davies suggested that this was nothing compared to what asylum seekers (or 'economic migrants' in his lexicon) go through - a mere dental examination could not be compared to the risk of crossing the Mediterranean and surviving the conditions of the 'Jungle' camp (also see Royston and Mills 2016). If they were 'real' children after all, what did they have to hide?

This event captures a number of different bordering moves around the body of the child, the 'real' refugee and the 'good' or domesticated migrant, bordering moves which are tied up with a powerful politics of victimhood, innocence and 'deservedness' and the visual regimes of all three. The figuration of the child does a huge amount of political work in this encounter and in global politics more broadly (Faulkner 2011). As I touched upon in chapter 4, 'the child' is bound to heteronormative futurity, and with this hope, and thus is made into the ultimate vulnerable subject. But this relies equally on who can be a child and, subsequently, who can be innocent, vulnerable and a subject of empathy and protection (Crawley 2011). It makes us ask which bodies are maintained by the dominant value of childhood, and how this might structure questions of mobility, borders and belonging more broadly. 


\section{Childhood}

Global regimes of humanitarianism rely upon the codification of childhood as victimhood, for example to 'save' and 'protect' refugees or vulnerable people. And yet we already know that childhood, and with that victimhood, is already racialised, gendered, sexualised in particular ways. Sharpe (2016) reminds us that childhood is never accessible to some. Consider how black children are consistently rendered as 'youth', and with this dangerous and threatening (Jackson and Pabon 2000; Duru 2004), often known only through violence, 'gang culture' or 'knife crime' (on asylum seekers see Davidson 2016), or how the above child refugees were immediately converted into a sexualised threat to white school girls. The messiness, cultural and geographical locatedness of childhood is obscured and often only made intelligible in relation to a white, Western and universalised idea of family. There is childhood, and there is sham childhood.

In the assertion by Davies that 'they don't look like "children"' we are reminded initially of how images of children work to create empathy in the context of humanitarian events and disasters; and secondly, of how this produces a grammar of 'real' suffering. Consider, for instance, the now infamous picture of Alan Kurdi, the toddler whose dead body was photographed lying face down on a beach in Bodrum, Turkey, in 2015. This picture is often upheld as a devastating and humanising moment of photojournalism (Gunter 2015). It is understood by many to have shifted the European public's perception of the 'migrant' or 'refugee crisis' and created the conditions for more liberal policy-making (including, some argue, the Dubs amendment discussed above; Bleiker 2018: 32). And yet, as Miriam Ticktin (2016) argues, this image was able to pull at Western heartstrings because the photo captured the dead child in the likeness of a Euro-American boy in holiday beach wear. It is significant that when I look at that picture now, I still see my own son. It is devastating. But this is fundamentally about who can be imaged, and at the same time imagined, as (un)worthy (see Butler 2010). 
Who gets to be a 'child' - known, seen, empathised with as a 'child' - is historical, just as who gets to be seen as a refugee or 'good' migrant is historicised within particular terms and relations of who is familial. In order to be accepted as 'genuine' refugees, or even to be mourned, children must fit within the dominant account of childhood and the family (Holland 2004). Or more precisely, they must be amenable to a population who can see them as their own children - as children that can slot into a national family and be protected, cared for, or grieved for by benevolent, white, European parents.

This gaze is not only present within Western media but it also organises the everyday practice of mobility. Human traffickers, for instance, are keenly aware of the racialised politics of vision. It is well documented that lighter-skinned refugees, particularly women and children, are often arranged on the top of boats crossing the Mediterranean, whilst black and darker-skinned people are often forced into bowels of the vessel. This is a stark reminder to Sharpe (2016) of the ongoing presence of the hold for black lives. Those thought to be seeable as 'real' refugees, as victims, as more human, are placed within plain sight in order to be counted worthy of saving.

\section{Visuality}

These bordering moves rely on ideas of who is the 'real' child and the 'real' refugee or 'good' migrant. But as I have begun to sketch out, this is always bound to particular forms of visuality, or ways of seeing. As well as not fitting within regimes of childhood, the children stepping off the coaches in Croydon could be photographed and rendered 'adults' and 'unchildlike' through particular visual techniques. Photography was used here not only to represent moving bodies but also to capture and render the inner truth of suspicious movement (Amoore and Hall 2009). As discussed in chapter 3 , the delineation between who is genuine/ in-genuine and deserving/undeserving (in this case the refugee) demands an ever-present suspicion of the intimacies and bodies of those moving 
and claiming rights. Likewise, this also relates to suspicions over relationships, kinships, age, the authenticity of identity documents and the recognition of embodied likeness (see Turner and Vera Espinoza 2019). As with the sham marriage, suspicion demands the use of technologies to extract the 'truth' from migrants, where deservedness can be read in textual evidence, images and on the body (from body language, skin colour, scar tissue).

In this context, the attempt by newspapers to use facial recognition software to test the age of child refugees is telling. Facial recognition software has become a key aspect of security practices and biometric technology which attempts to locate, categorise and capture subjects on the move - from airport scanners and passports, to checkpoints and police patrols. Despite huge technological problems with facial recognition software, making it almost practically useless for mass surveillance (Dodd 2018), it still continues to proliferate. Whilst most liberal arguments against such surveillance rely upon issues of privacy, we might consider the way this re-networks racialised codes of humanness (and with that 'childhood, 'adulthood', 'gender' and 'sexuality'). It works by codifying particular bodies as (ab)normal. Browne (2010) demonstrates how this technology relies upon the recognition of key facial feature that are attuned to a 'standardised' facial imprint of white Europeans. The 'normal' is coded through particular appeals to white 'epidemiological' features (Browne 2010). The use of facial recognition on child refugees reveals the ongoing circulations of the racialised body in visual surveillance of contemporary bordering.

It is worth dwelling on a further point regarding vision and race here. When David Davies argued that the UK government should subject 'unchildlike' refugees to dental examinations, he redeployed a key logic of racial/colonial science, one birthed from eugenics: that the facial, dental and bone structure of people should be compared, studied and categorised to extract the 'truth' of their character and morality. The supposed scientific promise to know the truth of the suspicious body (in images, X-rays, algorithms) is conditioned by colonial epistemologies and ways of seeing populations and bodies (Ittmann et al. 2010; 
Nishiyama 2015). This is not so much about 'fixing identities', but rather about finding the inner purpose, morality, danger and deviancy of particular subjects (Amoore and Hall 2009).

Davies also offered up another colonial 'truth'. In arguing that dental examinations should be brought in to test refugees, he made the case that they were already exempt from ethics and rights. Presenting the idea that they had 'been through worse' recognised that they had already been dehumanised. Or, they were never properly human in the first place. The proposal to X-ray these children is a culmination of 'thingification' (Cesaire 1972: 42). They are made into 'things', not people subject to rights and ethics, but caught in the racialised trap of the not-quite/ non-human. That is, they are made into flesh to be examined.

Here, the ways of seeing and imagining who is a 'real' child and thus a 'real' refugee or 'good' migrant, becomes conditioned by technology but also by histories of the visual. Photographs are one significant practice in the codifications of humanness, attached as they are to a particular national/civilisational grammar of suffering and empathy. 'Family' here is again both the quiet remainder and energising principle of such circulations. Family translates the seeable, it converts and modifies those that can be human-like, through welcome, threat or expulsion. ${ }^{2}$

\section{The good migrant}

Pictures are not simply of what things looked like, but how things were made visible, how things were given to be seen, how things were 'shown' to knowledge or to power - two ways in which things became seeable.

(Rajchman 1988: 91)

Drawing upon the example of the treatment of child refugees above, I propose that if borders are intimate (chapter 3), if borders are sticky (chapters 4 and 5), then borders are also visual. This chapter further pushes at the visual regime through which contemporary bordering operates. If the last three chapters focused on the explicit violent practices of contemporary colonial bordering, this chapter aims to examine how 
people are made to look 'out of place'. It does so, perhaps counterintuitively, by tracing the contemporary rendering of the 'good' migrant in the UK and beyond. It focuses on those mobile subjects whose presence is tolerated, welcomed, even 'celebrated' in the UK. Off the back of the contemporary governing promise that 'real' child refugees can be welcomed, that 'genuine' marriages can allow settlement, that the good, 'integrated', minority citizen deserves rights, I want to ask: what does this domesticated subject look like? Or to put it differently, how is the 'good', familial and integrated migrant imaged/imagined? That is, on what visual terms, and on what cultural codes and intimate relations, are moving bodies 'included', allowed to belong or at least 'pass' in contemporary Britain? It explores these questions by investigating the role of images and photography in both reproducing and contesting borders.

In the last two chapters I focused on how bordering/borders are energised by threats and dangers, from 'suspicious' to 'monstrous' intimacies. This arguably has led to reinforcing precarity, vulnerability and the abandonment of racialised settled and migrant communities alike. If the figure of the monster (terrorist, groomer, gang member) and the sham drives this bordering, so too does the figure of the 'good' migrant - the one who can be welcomed and included. Domestication, we should remember, is a liberal strategy: it includes to exclude. Borders need to be constantly redrawn around who is (un)domesticated, who is familial, who can move/settle, who is 'out of place'. It is from the potentiality of improvement, inclusion, progress that liberal government is re-energised. And with it, the violence that underpins domestication is equally rationalised and silenced. What I want to probe at here is how the promise of the 'good' migrant can also work to hide and remake the colonial hierarchies that dominate mobility and citizenship.

Consider, for instance, how the depiction of the 'good' child refugee - vulnerable, innocent, victim - conditions the unchildlike 'burly youth' or 'bogus asylum seeker'. Or how sympathy for victims of what became known as the 'Windrush scandal' in the UK have been used to justify the continued deportation of 'illegal' migrants (de Noronha 2018, 2019). Or how a fixation on women and men who have 'escaped' Islamic 
communities and joined 'mainstream society' (Razack 2007; Casey 2016) is used to justify the surveillance and discipline of Muslim populations more broadly. Who can be a subject of empathy conditions who can be forgotten or silenced, and who is unworthy. In exploring how 'good' migrants are imagined, and by this I mean made thinkable and seeable, I tease out how this creates further bordering moves. Delineations around who is 'good' are also key sites for colonial duress.

In this chapter I turn to the role that photography and exhibitions play in the making of the 'good' and, equally, 'familial' migrant. I first explore the role of photography in colonial domestication and in particular the place of family portraits in the ordering of intimate relations across empire. I investigate how photographs played a significant role in limiting who could be part of a family. I then bring this analysis up to date by considering the role of photography and vision in contemporary bordering both in the UK and Europe. This pays attention to the exhibiting of the 'good' migrant, which occurred during the 'refugee crisis' that came to prominence from 2015. I pay special attention to exhibitions and projects that claim to contest or challenge the dominant negative representation of immigration, mobility and settlement, and produce a positive account of migration. To analyse this in more detail, I focus on the photographic exhibition Arrivals: Making Sheffeld Home as one example of how positive stories and imaginaries are formed around migration, through appeals to local/global ideas about humanitarianism, as well as multicultural and civic nationalism. I thus explore what is contested and reproduced in these visual practices of inclusion and in making migrants familial, and more significantly, what the limits are to a politics of humanitarian or compassionate nationalistic welcome and inclusion.

\section{Photography and looking back}

Throughout this chapter, photography is treated as a key but ultimately part component of visuality - which is what Gregory (2012a) refers to 
as culturally contingent vision or way of seeing. In the use of 'visual regime' throughout the chapter, I refer to a series of components which work in a relatively autonomous but interconnected manner to make up a dominant way of visualising and constituting social reality. To refer to a visual regime is to consider both how things are seen and represented but also the ways that things are rendered historically seeable and unseeable (through techno-cultural processes). So, for instance, there is a visual regime of childhood. This is made up of different components (discourses, ideas, past images, visual techniques) and histories (heteronormative socialisation, Eurocentric ideas of the superior white family, commodification, racialised capitalism, gendering) that align to make, for example, one body look like a 'helpless child' and another a 'burly lad'. In discussing the 'gaze', I refer more specifically to a dominant visual regime that is tied to particular formations of social control and power relations. Mostly I speak, via bell hooks's (1992) seminal work, of the 'colonial masculine gaze'. This gaze was central to imperial and colonial government and continues to proscribe and haunt contemporary imaginaries and ways of seeing.

In studying how the 'good' migrant is imagined/imaged, this chapter engages with the politics of photography itself. Photography has historically been a key resource and product of the colonial masculine gaze, even as a creative and artistic enterprise. That photography has been relatively democratised (Bleiker 2018: 27) does not negate its role in empire-making. This is also reflected in humanist projects of modernity, where photography has been central to regimes of extractive truth telling, or used in practices of security and biopolitical management (Meek 2016). The legacy of these histories continues in bordering today, for example in the use of facial recognition software, security scanners at airports or biometrics in the control of mobility. As I demonstrate, photography also plays a key role in normalising and reproducing borders in everyday and mundane places like newspapers or art exhibitions, particularly in celebrations of whiteness (or in the case I examine, progressive/humanitarian whiteness). 
However, images - and photographic images in particular - also hold the power to disrupt. If photography remains a site of colonial domestication, this power is relational; it is constantly resisted and shaped by numerous social forces. Visuality and aesthetics play an important role in resisting bordering. Such analysis has been largely absent in this book and I attempt to introduce some of these questions here before expanding on them in the penultimate chapter.

\section{Photography as domestication}

Photographs are a powerful force because of how they relate to the claims of Western knowledge to access unmediated and scientific truths (Debrix and Weber 2003). Imperial and colonial rule was shaped by technological possibility of knowing, capturing and recording the 'reality' of territories, populations and movement (Jay and Ramaswamy 2014). From the inception of photography in 1839, the medium was tied into other practices such as cartography and demography in the governance of colonised people and lands. Photography could provide detailed records of lands, infrastructure and natural resources central to military strategy, surveillance or accumulation. We know that the power to see 'at a distance' was vital to the development of modern military power (Virilio 1989; Collins 2017). This was as true with the violent pacification and aerial bombardment of Iraqi civilians throughout the 1920s, as it was with the invasion of Iraq in 2003 and again in the expanding drone war that continues over the Middle East today (Gregory 2012a). Rendering territories and populations as seeable through still (and then moving) images is central to the art of colonial war and extraction (for more on this see Barkawi and Stanski 2012).

Movement again was constituted as both problematic and controllable within particular visual regimes. As we may remember from chapter 3 , visual identifiers were used by colonial states to mark out and categorise 
criminals, suspects or those moving bodies thought to be 'troublesome'. Branding was central to the control of slaves in the American South and the West Indies, tattooing and then fingerprinting was developed in India to make criminals categorisable and visible prior to the creation of photographic recognition and 'mug shots'. Photographic recognition would eventually be established in the passport and identity card systems of the late nineteenth and early twentieth centuries, but these were predated by practices such as slave ledgers and 'wanted' posters (Pegler-Gordon 2009: 11; Browne 2015). The recorded image shaped how the labourer, the rebel or the slave could be made knowable and classified (Thapar 2015), just as it made it possible to make lands and people primed for penetration and extraction - such as in the feminised images of the Orient as a space of sexual promiscuity and decadence (figure 1).

Said (1978) proposed that orientalism was a visual as well as textual regime. Colonial power required the construction 'of a sort of Benthamite panopticon' from whose watch-towers 'the Orientalist surveys the Orient

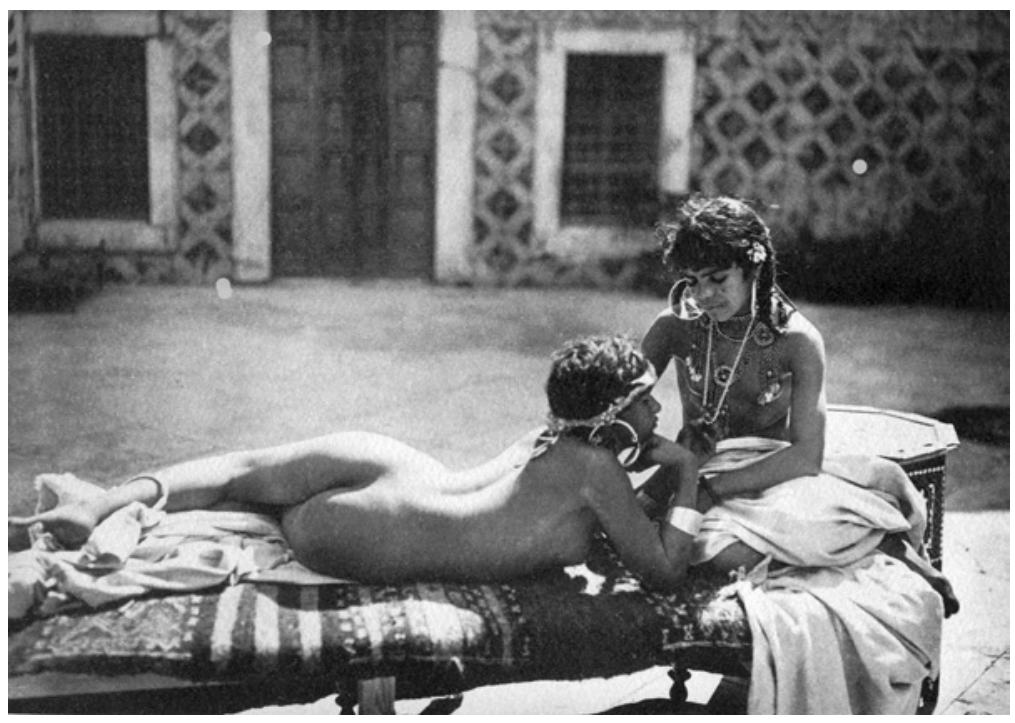

1 'In the harem', Lehnert \& Landrock postcard, 1900s-1910s 
from above, with the aim of getting hold of the whole sprawling panorama before him' in every 'dizzying detail' (quoted in Gregory 2012b: 152). This unidirectional and centralised analysis of vision has been contested (see Jay and Ramaswamy 2014). But we should remember how colonial administrators pursued photography as a means to visualise and thus make territory and people amenable to being governed. This worked both in terms of representing absences and producing places as familiar. The means of capturing still images as 'objective truths' could be used to reduce the complexity of social life into simple generalisations. To Mitchell (2000: 6-10), the colonial gaze was not always about taking pictures of the 'East' but instead making the East into a picture. Photography was a vital aspect of the cultural economy of imperialism, from travelogues and commercial photojournalism to postcards and exhibitions, which circulated images and imaginaries of the exotic/ erotic to populations across metroimperial space who were ready to consume the visual production of empire (on animals, imperialism and visuality see Margulies 2019).

\section{The state of the photo album}

The production and consumption of images also worked to manage racialised social relations. Colonial photography played a powerful role in constituting and distributing scientific racism. Coco Fusco (2003: 16) has argued that 'rather than recording the existence of race, photography produced race as a visualizable fact'. Photography provided anthropologists with an 'objective lens' to record and sensationalise ideas of human difference, progress and civilisation. European exhibitions often provided a space for such a spectacle, just as imperial and settler state archives held thousands of images of 'native' subjects for education, inspection and often entertainment (Maxwell 2000). Images provided 'evidence' of colonised people as savage and primitive, and as ethnographic records rather than people (consider the Savage South Africa exhibition described in chapter 1$)$. 
In the 1870s ethnographers Henry Huxley and J. H. Lamprey devised a systematic way of photographing aboriginal people across the British Empire. Their subjects were stripped naked and photographed in front of measuring apparatus, including a cross sectional mesh, so to compare anatomical characteristics. Huxley saw this as useful for racial categorisation but also to make judgements about the suitability of populations for coerced labour and other types of work in mind of moral 'uplift' (Maxwell 2000: 42-43). This ethnographic approach was contrasted with later cultural relativistic photography and more 'benevolent' methods of study where indigenous people were cast as bearers of unique and fast-disappearing cultures. In this way, colonised people were photographed as a mode of extractive racial categorisation, as a means of knowledge production for empire, for the benefits of imperial capitalism and as a spectacle to confirm European progress and development, which meant that images were produced and consumed as both for 'scientific' study and for titillation and desire.

Commercial and ethnographic photography was a key optic of the domesticating state, but equally artefacts such as family photo albums or portraits provided an intimate site for the production of coloniality, race-making and the scripting of the white self. Exploring the archives of colonial administrators reveals how colonised people were invariably conditioned as the observed - for example as 'house boy', 'labourer' or 'farm hand', 'native', 'criminal' - or as ethnographic remnants. The camera lens both provided a means of objectification but equally a technology through which the myriad of white colonial selves were performed - the adventurer, entrepreneur, philanthropist, home-maker, artist, socialite. Here it is important to recognise how this blurs (if not totally eviscerates) the line between what we might consider 'private' and 'public' photography - photographs are always public, even if meant for private consumption (such as those that find their way into official state archives - see the Bristol Archives British Empire \& Commonwealth Collection collection, for example).

The most striking example of this is the family album or portrait. Lalvani (1996) argues that photography did not merely reflect bourgeois 
colonial family values but was part of its architecture. Portraits, for instance, arranged particular codes of the white bourgeois European family - father, mother, children arranged in hierarchical order. According to Lalvani (1996: 65):

The family album is both a document of social assertion and a sentimental register ... The regulation of images, in providing for ' a common sexual and economic goal' and in enabling ideological oversight to permeate the private realm, plays 'a central role in the development in the ... ideology of the family.'

Drawing on Lalvani, we can consider how an artefact such as a hanging photograph becomes a means of shaping and producing 'family' and 'family memories' as regulatory ideals (Wexler 2000). This is significant because of the way photography works to frame normative ways of being but also because the aesthetic of the family photograph produces excesses and conditions who can be seen as 'out of place'. This is about what and who is permissible to photograph but also about how a photographic type relays continual 'truths', in this case intimate truths to be stored, displayed and treasured.

Just as photography was an intimate site of family-making in Europe, this was used in different social relationship across empire. Colonial administrators often focused on photographing domestic spaces as a means of showing how colonised land could be tamed and pacified, such as with fencing, gardening, the building of European style homes or bungalows (Mills 2008: 102-136). Colonised subjects were brought in to reproduce settler households within shifting codes of gendered and racialised stratification - as 'workers', 'gardeners', 'house boys', 'nannies', 'milk maids', or as 'lovers'. Importantly, colonised subjects could be partially included in the household but they could not be sustained or photographed as 'family' (see, for example, Stoler 2002 112-140). Whilst intimately connected, they remained subordinated and racialised labourers (as presented in figures 2 and 3).

This intimate inclusion/exclusion is important. The partial inclusion of 'good' colonised subjects within the settler household firstly reveals 
the racialised inequality of who worked for who under white supremacist capitalism, but equally this partial, often intimate, 'inclusion' in the household (such as the being viewed as the 'good house boy' or 'ayah'; see figure 2) works to obscure the dispossessive violence of wider colonial structures. It hid this violence by the appearance of intimate 'inclusion'.

The intimate dehumanisation of African bodies was often obscured in the complex 'inclusion' within colonial settler houses. But such pictures remind us of how easily black bodies were turned into objects, commodities or used as a spectacle of white pleasure and entertainment, such as in one infamous image of the African Oil Nut factory workers (see figure 3). It is significant that Badagry was a major Atlantic slave point, home to Gberefu Island - 'the point of no return'. As this photograph demonstrates, abolition did very little to alter such social relations.

The structure of the white colonial household and the family album was equally paralleled in the everyday experiences and visual registers of colonised subjects who travelled to the metropole, as British subjects, or after 1947 as Commonwealth citizens. Black and Asian photographers grew in number during the nineteenth and twentieth centuries. Their work often troubled dominant modes of visuality, for example by examining and representing kinship and belonging in alternative ways (see, for example, Gilroy and Hall 2007). Despite this, however, dominant forms of photography and popular visual culture in the UK focused on framing black and Asian subjects and communities as both inferior and 'out of place'. Consider how images circulated to reveal the problem of 'race relations' or orientalist codifications of exoticism (Tolia-Kelly 2016), of ungoverned domesticity and poor motherhood (Webster 1998), or inversely fixated on nostalgic images of a 'lost' whiteness, contaminated by decolonisation and the movement of black and brown bodies and intimacies. Reconstituting the colonial masculine gaze, Commonwealth citizen migrants were rendered visible along an axis of assimilable subjects who could be civilised into the marked space of the 'good', domesticated migrant, and those deemed unassimilable, who needed to be contained and expunged. 


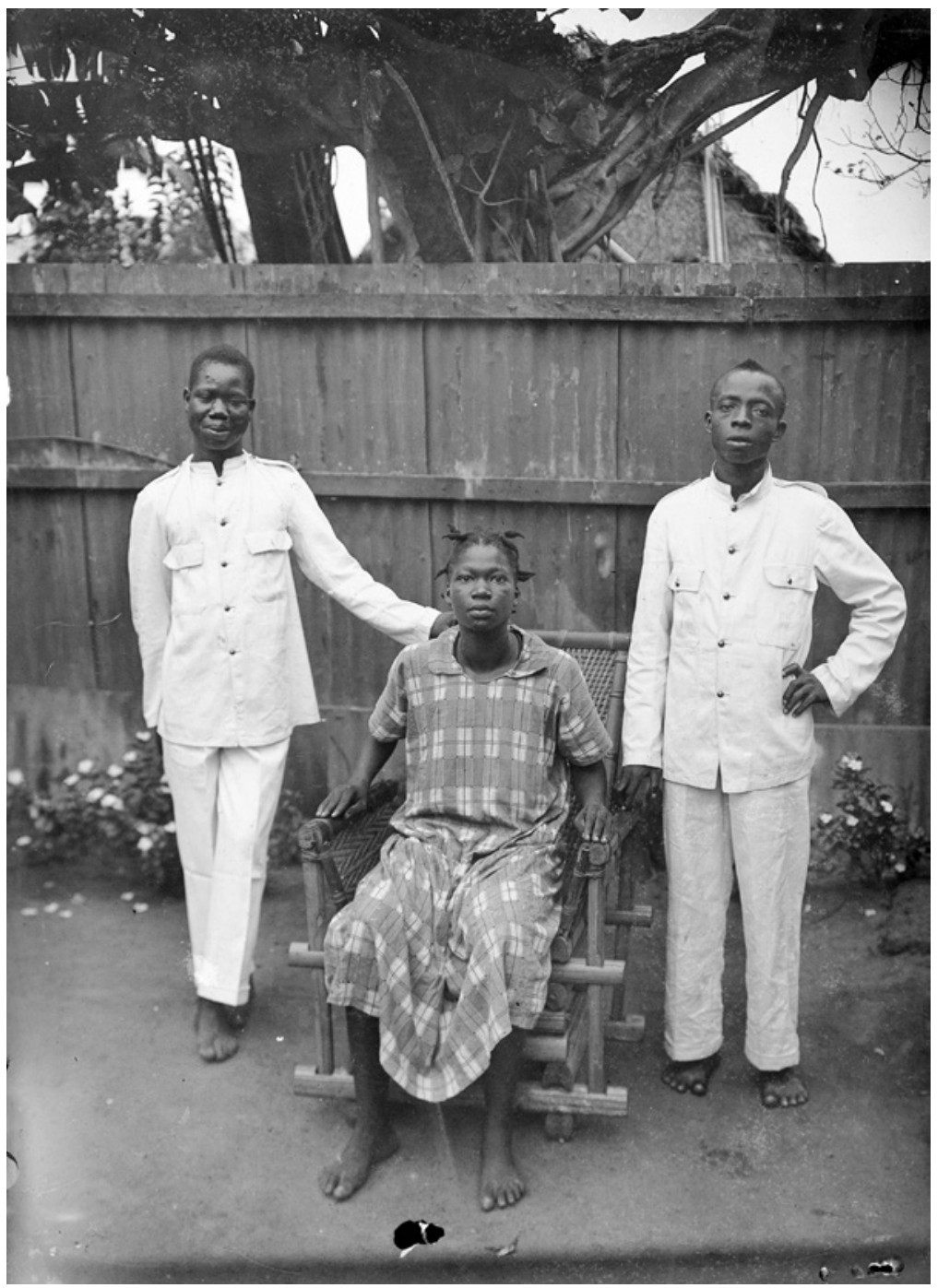

2 'My house boys', taken in Badagry, Nigeria, 1922, by 'Mr Verdin', manager of the African Oil Nut Company. He annotated the photograph 'My house boys... Godrey, James and Godrey's wife'. Godrey and James's subjugation within the colonial settler house is equally marked by the evisceration of Godrey's wife's name. 


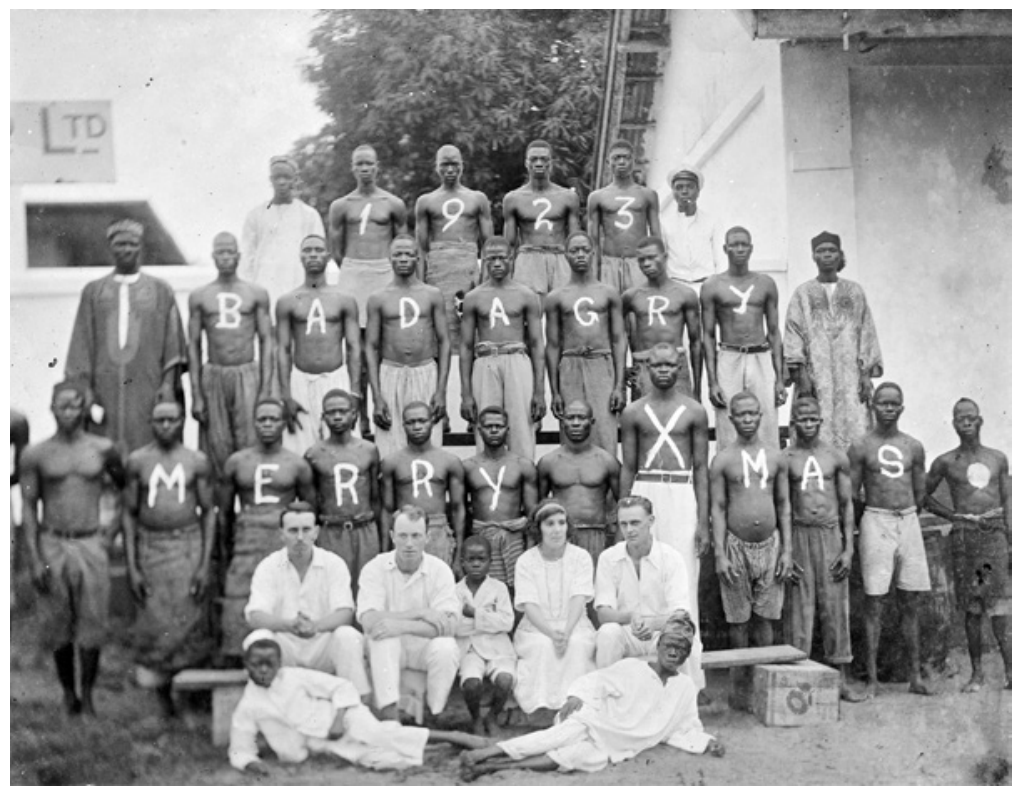

3 The Verdins' idea of a Christmas card (same photographer as figure 2), again taken in Badagry, 1923

\section{The family portrait}

If empire is always bound to family, as this book argues, then how could we think of colonial photography in relation to the family album or family portrait? If the family portrait was shaped by who could be photographed in relation to the family (settler household, white national family), we need to consider how photography worked to remake and normalise the treatment of colonised people: it demarcated who could be viewed as living outside modern time (ethnographic photography), or as an object of white consumption and subjugation (the family portrait), or as the primitive 'native' to be examined and preserved, or as a problem population 'out of place' (such as the presentation of Commonwealth citizens as migrants). Colonial photography worked to reduce personhood into bodies or things, as a subordinate to white personhood. In all of this, colonised people are materialised as in excess 
of proper familial relations with their appropriate gendered and sexualised codes of civilisation, nation, family.

Here the family portrait becomes the absent presence in photographs of colonised peoples and then people on the move. That is, it works to reveal what is missing or lost, figuratively or literally. As Wexler (2000) has argued, whilst colonised subjects and freed slaves took up photography, almost from its inception, not only did they face issues of resources and access but what could be recognisable as people and kinship within those photographs was shaped by the dominant white order. The colonial visual regime relates to how close one is able to perform European bourgeois domesticity. So, whilst some colonised populations were and continue to be cast as 'without family' - such as indigenous people or the enslaved - others are deemed as progressing towards heteronormative personhood. This is often revealed in how people were photographed or made seeable in relation to the (white) family portrait.

\section{Photography, control and mobility}

What I hope to highlight here is not just that pictures have symbolic power but that they also do things. It means thinking about how images are already placed within particular colonial power relations, bound to processes of domestication which circulate within imperial capitalism. Consider, for instance, how the portrait photograph became institutionalised into bordering practices through the emergence of identity cards and passports. The passport works through immigration law to constitute the individual subject as the holder of rights, but this is bound to how a subject resembles a photographic portrait - in other words, how they are 'seen' (see Torpey 2009). At the turn of the twentieth century, 'looking' like a passport photograph became one of the primary means for states to organise the movement of people, distinguishing between worthy/unworthy, the genuine/in-genuine (Browne 2015). This supplemented other visual practices such as medical inspections, and would eventually be proliferated in practices such as immigrant identity 
cards, police inspections and registration. Resembling a photograph became a dominant means of accessing rights of mobility and settlement and for authorities to expunge and control. How one is seen and made seeable matters.

As I touched upon in the introduction to this chapter, visuality plays an ever-expanding role in the government of mobility in contemporary states - from drone images and naval mapping, to heat tracing and facial recognition. Whilst northern states propagate these regimes, tracking, surveillance and imaging of 'events' such as the 'refugee crisis' in Europe is also done by international organisations, NGOs, militaries, corporate media and private security contractors, as well as by subjects on the move themselves (Tazzioli and Walters 2016). For instance, the United Nations Refugee Agency (UNHCR) uses visual recognition software called ProGres to profile asylum seekers, to manage their claims for refugee status, but also in the distribution of resources such as food and increasingly as a tool used indirectly in the push to deport those with 'failed' claims. The EU similarly relies on the Eurodac system to monitor the arrival of mobile people into the EU through fingerprint tracing as well as facial images - this data is explicitly used to track, contain and deport those back to country of entry or origin (The Economist 2017; for a long discussion of borders and biometrics see Scheel 2019).

Who is made invisible, who is pictured, who is imaged as a problem, who is imaged as in need of saving or as a 'good' or 'bad' migrant runs through these technologies and shapes the contemporary politics of mobility. But perhaps, as importantly, such a regime of visibility is also about invisiblity - who can avoid detection, who can escape or dodge the camera or the scanner. To Tazzioli and Walters (2016: 453), the governing of mobility is not merely enacted through the camera, but the 'dynamics which the camera imparts profoundly shapes' how bordering functions. This includes the possibility of not being pictured.

Whilst this regime of visuality is expanding technologically, photographs remain key to how state actors make judgements over suitability for the right to move and settle. Think again of how the UK regulates 
the movement of people by claiming that kinship ties or 'romantic' relations between subjects are invalid or in-genuine (chapter 3 ). This works beyond surveillance and the passport photo. Those moving on the basis of kinship, dependency or love often have to demonstrate 'family relations' through paper identification but also visual recognition (see Shah 2012). Here a 'family portrait' can quite literally become a legal document to evidence proof of intimate relations or be used as a justification for state officials to deny entry (White 2014). In the UK family migration visa application, for example, photographs are used to make claims over the subsisting and genuine nature of a relationship (Turner and Vera Espinoza 2019). This means that photographs are read for signs of love and intimacy by state agents suspicious of sham marriages (D'Aoust 2018). This raises questions about who has access to photographic technology (which is still overstated even in the era of mobile camera phones) but also the cultural history of how sociosexual intimacy is made intelligible. It relays a history of who can be recognised as 'familial' within the specific colonial terms of the (white) family portrait.

If borders are visual, we need to be attentive to the ways that mobility is seen and how migrants and mobility are imagined. In the next section I want to examine in more detail how particular bodies and populations are made to look not only 'out of place' but 'welcomable' - as subjects of 'inclusion' into the national or family space. Visual bordering works to distinguish the 'familial' and 'unfamilial', the 'worthy' and 'unworthy', the 'good' and 'bad'. Reflecting on how colonial photography was preoccupied with making colonised populations categorisable as exotic and/ or domesticable, I now turn to contemporary strategies to imagine the 'good' migrant.

\section{Imaging and imagining the 'good' migrant}

On November 2017 the Arrivals: Making Sheffield Home photographic exhibition opened in Weston Park Museum in the northern English 
city of Sheffield. To the collection's photographer, Jeremy Abrahams, this set of curated images offered an explicit 'counter-narrative' to the way that immigration and migrants were represented in the mainstream media in the UK (interview with the author 2017). In the context of the proliferation of dehumanising images of the 'refugee crisis' (Bleiker et al. 2013), of drone images relaying depictions of 'swarms' and 'flows' of people crossing into Europe in the summer of 2016, of nationalistic anxiety about 'foreign others' and 'cultural difference' and explicit policies designed to create a hostile environment, the exhibition and wider campaign was intended to display a positive visual story about migration. In this context, the exhibition sought to ameliorate the conditions of different people from across the world who were 'making Sheffield home' (Abrahams 2016).

This relied on the curating of seventy-two portrait photographs of people who had made Sheffield 'home', creating, it was hoped, a 'joyous and uplifting portrait of a creative and diverse city' (Abrahams 2016: 1). Reflecting international photo campaigns such as the International Organisation for Migration's (IOM) 'I am a migrant', each portrait was underpinned by a textual narrative of the subject's journey to the UK and practices of home-making. What was promised in the exhibition was that the portrait could be a frame through which someone stopped being a 'migrant' and became a 'Sheffielder', and in the civic terms of 'inclusion' could be viewed as a human (or at least more human). It is equally noteworthy that Sheffield is the next city over from Rotherham, the town that's name became a byword for grooming scandals and the scene of accompanied anti-Muslim (state) racism which I covered in chapter 4.

I want to linger on this exhibition because it offers an everyday site for what are both global and colonial logics surrounding the humanitarian 'welcome' of migrants and particular visual registers of 'good' migrants, 'integration' and multicultural nationalism in the UK. Furthermore, I am intimately entangled with this exhibition and campaign. The Weston Park Museum lies directly behind the department I worked in during the research and writing of this book. I would often walk through the 
exhibition space on my way to work or on breaks. After the exhibition closed, the photographs were displayed across the city and throughout the university. Several of the photographs now hang in the City of Sanctuary community centre, which aims to support and welcome refugees, asylum seekers and migrants to the city. Furthermore, the circulating politics of the images were invested in and claimed within the global and local struggle to welcome people on the move. This joins other campaigns by IOM, UNHCR, international art exhibitions and activist groups to provide a humanitarian response to moving people, in which refugees and migrants are made welcomable.

The dominant visual regime of contemporary migration often found in the news media is preoccupied with images of boats, masses, camps and imperilled victims. It is often organised around both the dangerousness of black and brown men and also the hypervisibility of what Enloe (2018) calls 'womenandchildren'. This visual regime has been revealed as dehumanising and orientalist by numerous scholarly accounts (Johnson 2011; Bleiker et al. 2013; Philo et al. 2013). What is less obvious is how positive and humanising visual regimes may have similar effects.

The visual terms of who can be welcomed and included in the UK are thus important for how we understand the politics of bordering and its ongoing colonial orientations. Not only do such exhibitions energise bordering but they also connect up with and reproduce a broader visual regime which makes particular moving bodies 'out of place. Exhibitions such as Arrivals are not isolated events; they render often very explicitly what are wider logics and circulations of ways of seeing people. Here I want to consider questions of visibility with regard to the exhibition and construction of the 'good' migrant - that is, who is viewed as welcomable and how this welcome is made intelligible. But I also want to explore invisibility - who, or what, is obscured and unseeable in these campaigns. The exhibition is not read here to responsibilise anyone, but rather to understand the logics, assumptions, silences that shape and are reproduced across the both the photographs, the narrative of the exhibition and the local and global discourse of the 'good' migrant more broadly (see, for example, Shukla 2016). 
In utilising the medium of portrait photography, the Arrivals exhibition partakes in a wider global push to 'humanise' migrants and redraw borders in relation to more cosmopolitan and liberal logics. The intention of Abrahams's (2016) campaign was to 'remove immigration from the zone of contention ... and to humanise it through images and stories of people who have migrated from around the world. This connects up with humanitarian approaches to contemporary mobility, where the assumption is that if only northern publics could see migrants as equally human - or more precisely, as individuals and people - they could empathise with their plight (see Johnson 2011). The stress here is on how the deaths of people crossing the Mediterranean in particular are ungrievable (Butler 2010) because of the way they are dehumanised as collectives and though animalistic metaphors - as 'swarms', 'hordes', 'cockroaches' and so forth.

Portrait photography has become the go-to medium for the visual counter-practice of humanisation. ${ }^{3}$ Rather than focusing on mobility, collectivities or masses - a focus which is viewed as dehumanising and replicating a racist field of vision - the portrait photograph is supposed to show to the audience the humanity of the migrant. This follows social-scientific research which has evidenced how pictures of individuals and particularly images of faces tend to energise feelings of empathy and compassion in audiences (Bleiker et al. 2013). Jenny Edkins (2015) reminds us of how the history of the portrait is always concerned with the biography of the liberal self and its quest for wholeness as a symbol of the human. Arrivals relays this logic in the composition of images which foreground the face and body of its subjects. Rather than situating the 'migrant in peril', the stress of these pictures is on the inclusion and home-making capacity of its subjects, who are pictured as embedded within the urban fabric of Sheffield. Differing from the humanitarian images of disaster, it is not suffering that is supposed to humanise the migrant in Arrivals but rather their capacity to function within the cultural and productive economy of the city and nation. This is the visual cue of their relatability and the promise to 'become human'. 


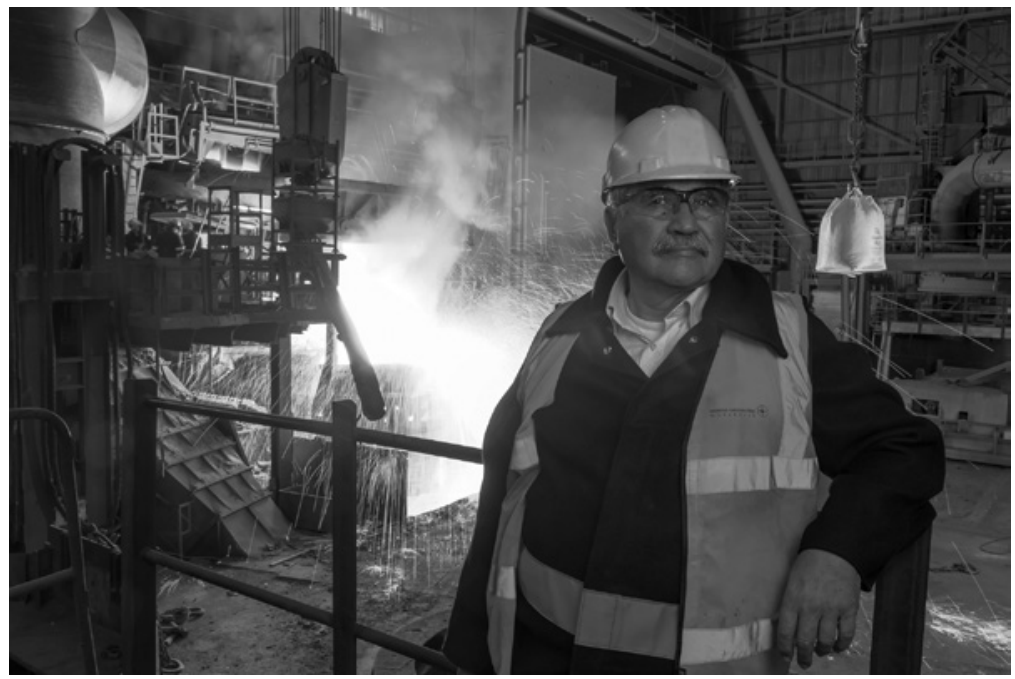

4 Pedro Fuentes, photographed by Jeremy Abrahams (2016)

Take, for example, the photograph that opened the Arrivals exhibition and campaign: Pedro Fuentes is pictured in Sheffield Forgemasters, perhaps the city's most famous steelworks (figure 4). The hard hat and goggles worn by Fuentes relate to his role in the steel industry, just as he is positioned in front of the kinetic sparks of the furnace. Fuentes is captured in the very symbolic heart of the city, which prides itself on its industrial past (and steel-making in particular). We should note here how the foreign body is rendered as 'integrated' and made 'useful' in relation to both the city's and nation's industry of production. The terms on which Fuentes has made a 'home' and is made 'welcomable' is depicted through the masculinised role of his labour. This is key to the substance and renewal of the city's economy as well as nostalgia for its place in the circuits of imperial capital and wealth. The terms on which Fuentes can be viewed as 'at home' in Sheffield, as a masculinised labourer - contributing by producing steel - is tied to the wider role that 'contribution' has in the politics of mobility in the UK and beyond. 'Contribution' has become key to figuring who is a 'good' and worthy migrant, and equally who is redundant, 'illegalised' or deportable. 
'Contribution' (i.e. through work and labour) is superficially economistic. But this understanding of economic value is bound to circulations of heteronormativity and with it racialised accounts of the nation. As I have previously argued, the liberal account of nationhood relies on making distinctions over who produces economic and cultural value, tied as this is to inclusion in the labour market, principles of selfgovernment and progressive familial intimacy. As I showed in chapter 3 , this is how multicultural difference is pacified and presented as deracialised in liberal discourse. Contributing is to be forward-facing, modern and to reproduce for the nation (Berlant 1997: 83-85). Fuentes can be welcomed because his body is rendered central to the reproduction of the city's (and thus the nation's) symbolic and economic value.

In this way, the question running through the Arrivals exhibition could have been: what have migrants contributed to Sheffield and the UK? What are they 'giving back'? Or as Ahmed (2010) reinterprets it - they are merely 'giving back what they owe'. These photographs reveal subjects embedded in the city's urban space but also as tied to key economic and civic institutions: the town hall, cathedral, city parks and universities. This visual narrative of place and value is intended to trouble the outwardly hostile depiction of the migrants as a 'drain on resources', as social and economic 'parasites' or as an unintegratable subject of 'cultural difference' (think back to chapter 3). Instead, the 'good' migrants - those who can tell a positive story about migration - are rendered as both normal participants in the city's/nation's economy of value but also exceptional, 'gifted' and talented contributors. ${ }^{4}$

Contribution is not only visualised in economic and civic terms in the Arrivals collection but it is also codified through love as a circulation of value and progress. Just as I examined love to function in relation to the white family or nation in chapters 3 and 4, love here brings together different points of contact. Whilst many of the portraits capture individualised subjects, a number focus on heteronormative and familial love as key aspects of home-making - as anchoring proper belonging (see below). Starting a family and especially having children is central to the exhibition's attempt to explore what a 'good' migrant is and what 
a domesticated subject looks like. What is emphasised across the exhibition is how people either 'travelled for love' or 'found love' in the city. Heteronormative (and to a far lesser extent homonormative) familial love circulates across the photographs, such as in the focus on close body contact, holding hands, touching on a sofa, hugging children. Here 'proper' familial intimacy is offered as the solution to the challenge of mobility and belonging.

But love is also projected onto the people of Sheffield and the city. The 'good' migrants are not only shown as embedded within the urban/ national space and within heteronormative domesticity but their contribution (what makes them 'good') is also found in their expression of love to those who welcomed and 'hosted' them. This love is orientated towards both the people of Sheffield and correspondingly the nation. 'We love Sheffield, its friendliness, trees and parks, its civic culture', is a common sentiment expressed through the exhibition. Here the migrant story is presented as one of displaced violence which is fixed by the love of the host nation. This is particularly the case for those who have claimed asylum or been guaranteed refugee status. Here violence and state oppression are rendered a 'nightmare' - spatially and temporally positioned elsewhere, far away from the city in past lives and foreign lands - whilst the transfer of love, welcome, tolerance is grounded in Sheffield and Britain.

The visualisation of love throughout the portraits is not only found in examples of heteronormative intimacy and domesticity but also in the relationship to productive activities - such as gardening, painting, civil society activities and paid labour - and in emotional appeals to codes of happiness such as smiling and laughter. Here the contribution of the migrant works to ameliorate their difficult presence. Their difference and potential for diasporic melancholy (Brah 1996) can be diffused by appropriate intimacy and the expression of grateful love and happiness at being 'here' rather than 'there'. This is given away in the promise of the exhibition, which is to provide a 'joyous and uplifting portrait of the city' (Abrahams 2016: 1). Love is not only to build heteronormative relations to secure the future of the multicultural nation but also to be 
happy, to commit to and to love the new home. We come to know that the 'good' migrant is the 'loving' migrant.

Love thus works in this context to make certain migrants 'good' and familial. But love has another function: it equally works to obscure and make 'difficult' experiences of racism and the 'imperial grooves' of mobility unseeable (and forgettable), even when accounts of racism are explicitly raised in the exhibition. In juxtaposition to his smiling portrait, Abdi Aziz Suleiman describes in his story how the racism he experienced in the UK 'was like a grenade thrown at the foundations of our carefully constructed confidence' (Abrahams 2016). This is a powerful intervention. And yet despite several contributors raising the issue of racism in their stories, the visual regime of the exhibition is figured towards the celebration of joy and positivity and love of the city. This means it is unable to explore the poetry of Suleiman's words. Instead, the images of 'good', civic (and often white European) migrants feeling love/lovingly functions to smooth over these cracks and difficulties, or works to push racism into being a thing of the past. Racism is something that could occur in the 1950s, goes the refrain, but not now. Through a focus on joyous love, struggling against institutional racism is rendered unrepresentative of the 'good' migrant experience. It does not fit within the register of being happy and loving one's host society. Ahmed (2010: 144) reminds us that the 'melancholic' migrant who holds on to racism and struggles with it is always an obstacle to the happy and loving nation. Thus, to be a 'good' migrant is to let go of race and learn to love. Love not only smoothes over the force of institutional and structural racism and violence in the UK but it does so to pacify and make certain migrants look 'familial'.

Here it is worth considering which bodies are presented as indicative of the 'migrant experience. The Arrivals exhibition works to create a visual register where EU migrants speak from the same position as non-European migrants and subjects who travelled from ex-colonies - often as Commonwealth citizens. This is also a common liberal strategy in global campaigns (IOM, for example) because, after all, moving is viewed as 'universal.' This firstly eviscerates different positionalities and 
global-colonial inequalities. It secondly works to hide racialised, sexualised, classed and gendered structures and experiences. Whilst people of colour in the exhibition attempt to raise the issue of race and a more complex claim to belonging, white European migrants empathetic appeal to the love of the city and place allows them to speak for all migrant experiences, and to whitewash the experience of others through their happiness and joy. We are reminded here that the good migrant of colour must overcome injury and prejudice for the future endurance of the multicultural nation into which they can (partially) 'belong' (Fortier 2008).

\section{Visual borders}

What we learn from such exhibitions and the wider logics they shore up and distribute is that the 'good' migrant 'contributes'. This contribution is materialised as different types of value: love, individualism, heteronormative family, domesticity, happiness, forgiveness are all terms on which the migrant is visualised as good, included and thus domesticated within 'multicultural' Britain. The visual regime of the Arrivals exhibition works because it reproduces wider local/global registers of recognition, such as humanitarianism and multiculturalism, but codifies this in local/ national terms. Here 'family' works as a developmental logic, revealing and demonstrating humanity and progress, and making migrants welcomable.

Elena Fiddian-Qasmiyeh (2016) argues that the promise of the contributing migrant has come to dominate the treatment of mobility globally. Following on from the logic of contribution that we saw with Arrivals, she highlights the expansion of the 'super-refugee' (e.g. the Olympian swimmer who has overcome obstacles to achieve herculean feats, the hypersuccessful entrepreneur, the genius who changed the world). To be welcomable, the refugee must evidence being an 'exceptional person' or an exceptional contributor to humanity and nation. In parallel, this motivates the exceptional act of welcoming refugees 
and migrants by European publics (Fiddian-Qasmiyeh 2018). Whilst expressively about welcoming and revelling in difference, these examples remain orientated towards both a global humanitarianism and a local 'compassionate' nationalism, which draws borders around who can be empathised with and who cannot, translated as who can contribute to and benefit the civilisation and/or the nation and who cannot. In this way, the reification and materialising of the 'good' migrant, such as in the exhibition Arrivals, can be thought of as a site of bordering. Here it is important to recognise that sites such as exhibitions matter because of the way they benignly reproduce broader local and global logics, and they do so whilst appearing to be 'unpolitical' and merely about 'humanity' or 'art'.

But I do not want to just leave this here. Such sites normalise ideas about the good/bad, worthy/unworthy. But they also do work to complement and energise powerful modes of domestication. We need to remember the significant role photographs and images play in the control of mobility in the codification of who can have rights, move, settle. Sites such as the Arrivals exhibition can be viewed as part of a connected visual regime which actively materialises who looks 'out of place' and who 'belongs'. We can think here of how bordering criss-crosses such a set of images, reifying certain figurations (the 'good', familial migrant) at the same time as producing other absent presences (the unintegratable woman, the rebel, the terrorist, the illegal, the monster, the melancholic and angry migrant or citizen of colour, the sham family - those who love and inclusion cannot be extended to, who cannot be imagined as familial). If welcome can be extended to those who fulfil the criteria of the 'good' migrant, this redraws borders around those who remain risky and those who need to be expunged.

Within the wider construction of humanitarianism and the visual regime of migration, this set of images does further political work and bordering. To Abrahams (2016, my emphasis), the exhibiting of these images proves that that 'they have indeed become part of our community'. They have proved to us their inclusion and thus their worth. As with wider humanitarian visual regimes of migration, the exhibition is 
orientated towards proving both the national value but also humanity of the photographic subject. As with wider humanitarian visual regimes of migration, the exhibition is orientated towards proving both the national value but also humanity of the photographic subject. This form of humanitarianism works to coax empathy and compassion out of a 'host' society - which is imagined to be nationalised, settled and predominantly white. Not only are migrants imagined to be exceptional contributors and benefactors for the host community - in other words, they can be included because they are good families, good workers, good civic leaders - but they are also expected to be forever grateful for the benevolence of the host nation.

Arguably, what is hidden through the intimacy of the portrait photograph is not only the institutional racism suffered by black and Asian migrants but also the colossal architecture of bordering which traps, contains and excludes racialised and mobile subjects. As with humanitarian appeals to help those suffering, this works to hide the violent architecture of borders and the complicity of the white audience in these structures. As with the inclusion of colonised subjects within the domestic space of the colonial household, the 'good' migrant is not only subordinate but their presence is only 'good' when their lives are put in service of the economic, social and cultural renewal of the postcolonial nation and family. We might consider a parallel here with the colonised subject who was intimately included or excluded from the settler household. In this way, the 'good' migrant is haunted by the image of the colonial 'house boy' whose subordinated presence and proximity both reveal and hide dispossessive violence. This parallel to the colonial 'house boy' works to hide how racialised populations are contained and continually interpolated as not-quite/non-human.

Humanitarianism, and its accomplice compassionate nationalism, ignores the intimate violence of bordering, which as I have discussed in this book is far from 'elsewhere' but in fact is intimately bound to racialised governance in Britain. My point here though, is that these images matter because of how they map onto and reproduce wider local and global visual regimes and how this feeds into other border 
sites. Images of who is a 'good' migrant circulate and feed into a wider landscape where decisions over who can move, settle and claim rights are taken. The happy, loving, heteronormative/homonormative and contributing migrant has social power.

Given how authorities work to distinguish who looks suspicious, a sham or a monster, the figure of the 'good' migrant circulates and energises distinctions over who looks welcomable and who looks dangerous. Consider how refugee resettlement schemes prioritise protection to 'children' and 'families' in camps across the Middle East, or visa regimes are orientated towards productive individuals through the UK tier system, or how moving as a dependent of a settled person is conditional upon looking like a spouse/partner or dependent child. In all of these sites, authorities make distinctions over who can be included premised on clear visual registers of who could be a 'good' migrant. This is more than an issue of (mis)representation. Instead we need to recognise that because borders are visual, the imaginary of the 'good' migrant helps play a part in creating the conditions of who can move, who can be given rights and who can be expelled. In light of this, consider the figures for the scheme for the resettlement of unaccompanied refugee children to the UK which we began this chapter with (of which the Dubs amendment provides one particular route to settlement). It was widely publicised in 2018, in the wake of the 'unchildlike' child refugee scandal, that only twenty child refugees had been resettled from camps in the Middle East (out of three thousand places initially promised). It was also noted that resettlement from informal camps in Calais has almost ground to a halt (Townsend 2018). Who can be imaged/imagined as a refugee or a 'good' and welcomable migrant matters.

\section{Humanising migrants}

As I noted above, portrait photography (such as illustrated in the Arrivals exhibition) is frequently offered as a solution to the explicitly racist representation of migration in the mainstream media - from the drone 
images and biometric scans, to the photography of crowded boats. This reflects broader ideological principles and assumptions that run through the politics of liberal inclusion and humanitarian welcome more generally. This means that we should ask what assumptions run through the 'humanising' promise of the portrait photograph and its focus on the 'human face'.

It is telling that in her discussion of colonial photography, Maxwell (2000: 44-45) argues that portrait photography offered more dignity to colonised people. It was 'humanising', regardless of who was taking the photograph or for what purpose. Against older practices of ethnographic recording, the portrait is viewed as empowering subjects, because those subjects could meet the colonialist gaze and be given 'equal' status as a nameable subject. However, Maxwell's argument and the liberal humanism that dominates the welcome of people, locally and globally, arguably falls into the trap of wishing away the power relations of photography, its cultural location and the visual regime and hierarchies it helps to maintain.

Through the proliferation of the masculine colonial gaze, acceptance and inclusion into personhood has been premised on being able to be imagined (if never included) as part of a family portrait, as a series of gendered and sexualised relations within the family home. The examples of child refugees, or the imaginary of the 'good', contributing migrant, demonstrate how the very conditions of personhood are mediated by who is, or can be imagined to be, part of the national/civilised family. Just as the family portrait was the frame through which colonised subjects were offered claims to their humanity (by whether they were able to look like a family), the portrait does similar work to obscure and hide who gets to be viewed as human.

In appealing to a humanitarian logic of empathy and compassion, or a joyous celebration of diversity, migration is viewed through portrait photography as a universal human journey. This has become exemplified in focus on the human face as universalising. The structural conditions and imperial grooves that continue to move people, and move people to the UK, are unseeable in this apparently universal story. Take, for 
example, the historical conditions such as transnational diasporas, connections through imperial language or ongoing forms of neocolonial warfare, capital accumulation, global inequality, kinship ties. This humanitarianism is repeated in similar naive cosmopolitan claims such as 'we are all migrants' or 'all refugees', a position which obscures the history of colonial violence and inequality that both created borders and sustains the movement of people to the Global North.

In viewing the portrait as humanising, this also firstly assumes that the humanity of migrants must be evidenced. This is problematic on its own terms, but even more so here because being photographed is the medium through which the migrant is supposedly transformed into the human, as an individual subject who is complete and thus relatable to as 'human'. As problematically, this equally assumes that humanity is judged by the spectator. Under this logic, the person of colour and the migrant can only be included as human once they have been made visible through the dominant techniques of portrait photography, and by the visual codes and relatability of the 'good', contributing/familial migrant. Ultimately, the migrant awaits to be transformed into human by being pictured and then being witnessed and accepted by a predominantly white audience.

What I want to stress here in this reading is that rather than breaking free or challenging violent borders, the universal appeal to the human, compassion and empathy found in the imaging/imagining of the 'good' migrant' not only obscures but reproduces colonial bordering. In idealising the 'good' migrant, this hardens the boundaries around the 'bad' migrant. This equally works to conceal and hide the violence of bordering. It does so by reproducing the patronising and paternal but also intimate offer to be included within the family/national home that we witnessed with the treatment of the colonial 'house boy'.

\section{Whiteness and compassionate nationalism}

Whilst contesting explicitly racist and nativist accounts of migration, such as from the far right, the visual regime of the 'good' migrant and 
leftist-liberal humanitarianism also arguably reproduces many of the assumptions of the white nationalism it supposedly contests. This is because this visual regime is geared towards satisfying an audience that people rendered 'different' (often encoded racially) can be pacified, made like 'us' or can even be 'good for us' (i.e. they can love 'us' or contribute for ' 'us'). But also, because this works to praise the tolerant understanding and even 'love' of the host community, white spectators are invited to imagine themselves as benefactors, compassionate and ethical subjects. The working of racism, and with it gendered and sexualised inequality, is concealed in this appeal to a tolerant community, just as (neo)colonialism and the questions of what continues to move people are completely erased.

What I argue is manifest in the imagining of the 'good' migrant is in fact a re-scripting of colonial whiteness (also see Danewid 2017 for a comparative argument). It is the outward rejection of a xenophobicracist nationalism and the reformulation of a supposedly compassionate and humanitarian nationalism. But what haunts both accounts are appeals to white innocence (Wekker 2016). Compassionate nationalist accounts have particular traction on the liberal left in the UK - where the 'civic nation' is reimagined alongside an appeal to British values of democracy, equality, tolerance and 'postracialism' (Fortier 2008). We see its inflections in the commitment to integrate Muslim women out of their troubled domesticity, or in attempts to work in solidarity with refugees, or in the push to protect the rights of 'Windrush generation' citizens who are threatened with deportation. This humanitarian leaning and often multiculturalist nationalism 'includes' and even celebrates diverse others, whilst constituting them as 'welcomed' guests of the original (unmarked but white) nation.

Ida Danewid (2017: 1682) argues that this compassionate nationalism is concerned with a re-scripting of the white national and civilisational self around ideas of tolerance and solidarity. It involves a reimagining of the white self, who is now bound to multiculturalism, migrant solidarity and liberal hospitality - values which in themselves seem appealing to a progressive audience. In this setting the reaction to the approach of 
the migrant 'stranger' is one of empathetic welcome rather than hate and vilification. On the surface, this seems resoundingly positive. However, such a position of empathy fails entirely to produce a critique of the colonial masculine gaze and instead merely reinvigorates it. Just as with the Arrivals exhibition, under humanitarian and compassionate nationalism the migrant other is consumed and included, but only to renew the white national self and to evidence and celebrate the tolerance and benevolence of those who identify with it. Consider, for instance, how contribution is viewed in terms of the economic benefits the migrant brings to the nation, or the 'love' and thankfulness they demonstrate towards their 'hosts.' Or equally, how the 'good' migrant is made welcomable by evidencing their exceptionalism. Such 'cannibalisation of the other masquerading as care' (Hemmings 2012: 152) is made possible by historical amnesia and the erasure of colonial dispossession, violence and the visual regime of 'humanity'. It involves an active forgetting of the connecting tissue that moves people to Europe and the UK and the violence and exploitation that did and still accompanies this relationship. These tissues have been created through formal colonialism, the accumulation and dispossession of imperial capitalism and in ongoing colonial war in the Middle East. This position of humanitarian/compassionate nationalism may not be explicitly nostalgic for empire, but it only works by hiding this history and by promising to offer the migrant their humanity back as a part of their inclusion in the national family. However, as I discussed in chapters 4 and 5, inclusion in British citizenship for the once colonised is always a failed promise.

Not only are the boundaries between 'good' and 'bad' migrants reestablished in this discourse but this type of humanitarian and compassionate nationalism is a complex work of resuscitating white social relations on the terms of empathy and progressivism (Danewid 2017). Firstly, this works to dehumanise migrants by 'offering' them their humanity through the spectacle of being welcomable. Secondly, it renews what Wekker (2016) has called 'white innocence', which works not only to silence colonial histories and presents but also actively works to preserve the unjust structure of the status quo and its visual hierarchy 
of the human (also see Mills 2017). The imaginary of the good migrant not only structures bordering around who can be included or excluded but it is also used to reproduce and renew the very structures of white nationalism that deny migrants humanity in the first place.

To consider the visual regime of the 'good' migrant we have to consider how it is connected to a celebration of the white family portrait. Recognising this is important for understanding the distinct limits and silences of attempts to 'humanise' people on the move, which has become so central to contemporary logics and counter-visual practices of humanitarian and compassionate nationalism.

\section{Conclusion}

I started this chapter by demonstrating how mobility is regulated around who can be imagined as a 'good' migrant. Child refugees can be transformed into 'burly lads' by a visual regime of childhood which makes certain bodies 'unchildlike' and subsequently undeserving of rights. This helps us understand how borders are visual, as they are 'sticky' and 'intimate'. Being made 'out of place' is also a product of being made visible as 'out of place. This follows the increasing way that borders rely upon visual technologies to distinguish and categorise people, to track movement and manage access to rights. Imagining who belongs, who can be welcomed and who can also be expendable is also about who can be imaged as such. But this imagining/imaging is constantly wrapped up in the politics of family, who can look domesticated, who can look familial - as 'wife', 'husband', 'partner', 'child', and we might extend this to 'good neighbour', 'civic actor', 'citizen'.

This, I argue, relates to a wider interlinking history of colonialism and visuality of which photography is an important part. In exploring the role of photography under wider empire I demonstrated how images were central to race-making and presenting people as objects, commodities or other. Photography was central to the regulation of populations through warfare and anthropology, just as it was in organising 
the intimate relations of the colonial household. Family portraits, for example, stand as a key means of arranging who could be counted as worthy of family and who could only work for the family (as 'house boy'/'labourer'/'ayah'). Photography helped arrange often-intimate hierarchies within households where colonised subjects could be 'included' but only as subordinate and never as properly familial. This point is more than about symbolism. With the networking of photographs into the global regulation of movement, through identity cards, passports, surveillance technologies and visa applications, images (and with them ways of seeing people) have become powerful sites of bordering.

In pushing this book's argument that borders are dispersed and networked through more than immigration law, I turned to how activist campaigns and art exhibitions play an important role in the imagining of 'good' and familial migrants. Rather than focusing on delineations of sham or monstrous others, I explored examples of where migrants are celebrated and 'humanised'. Using the exhibition Arrivals, I revealed how humanitarian logics of 'welcome' fail not only to contest right-wing and explicitly racist depictions of immigration (that is, as disembodied hordes, dangers, deviants) but also reproduce heteronormative whiteness and a forgetting of colonial violence. Rather than an endless imperilled victim, the 'good' migrant here is presented as the contributing, loving, familial migrant. 'Family' here works as a developmental logic. It shapes claims over who is worthy/unworthy. It is on these terms that they can be 'included' and offered 'humanity'. This again is far from being only symbolic. Just as with the example of the child refugees, who is made seeable as the 'good' migrant is central to how mobility is regulated and how colonial sensibilities are reformed and reworked. Bordering in sites as distant as family visa applications, refugee resettlement programmes, points-based immigration systems, works to offer rights, mobility and settlement based upon fulfilling the terms of the 'good' migrant.

Whilst a celebration of the progressive white self who can welcome distant others, the humanitarian and compassionate nationalist logic we can see circulating in northern states is both limited and paternalistic. The welcome of the 'good' migrant can be treated as a recycling of the 
position of the colonised 'house boy' who was offered an intimate place subordinated within the colonial household, only ever to work for the good of the 'real' family/national home. This does nothing to alter the terms under which bordering continues to make people 'out of place', nor does it work to challenge the way that structural logics of racialised violence continue to drive government in the UK.

If, as I have argued, the colonial masculine gaze still dominates ways of seeing, what of hooks's (1992: 115-116) provocation of how colonised and enslaved people look back? If humanitarian logics merely replicate colonial ways of seeing, what other alternatives, what other ways of looking have worked to resist and look away from this visual regime, and with it, colonial borders and the power of family? It is to this question of other counter-visual practices and resistance to bordering that I now turn.

\section{Notes}

1 Although it was hoped this might make way for wider scheme of up to three thousand resettled children.

2 This chapter is based on archival work undertaken in 2017 and 2018 at the Bristol Archives, which holds the Commonwealth Photography archives. It also draws upon ethnographic and observational field work conducted at several exhibition sites - the Weston Park Museum, Sheffield, the Bristol Museum, the British Library, the Migration Museum, London, and interviews with photographers, artists and participants. I visited galleries, exhibition spaces and museums that hosted events and exhibitions on mobility, empire and family across an eighteen-month period (2016-2018) At the core of this chapter is an engagement with visual analysis (Bleiker 2018) which aims to investigate what Gregory (2012a) calls the techno-cultural history of photography, mobility, race and borders. Rather than focusing purely on visual methods as a form of representational practice, I consider how visuals (photography in the main) emerged within the history of colonial expansion and warfare and how the very technology we tend to consider as neutral and objective is culturally and politically located within colonial modernity (also see Virilio 1989). This involved examining common themes and styles of photography across archival photographs, moving images, family portraits in the late nineteenth and early twentieth centuries (predominantly in the British Empire \& Commonwealth Collection in the Bristol Archives), investigating visual methods and surveillance during this time, such as the rise of the passport, and examining the styles, representational 
practices and techniques used in photography exhibitions on human mobility in 2016-2018 (in exhibitions across Britain, as noted above).

3 For similar themes, see National Geographic, 'The New Europeans', available at www.nationalgeographic.com/magazine/2016/10/europe-immigration-muslimrefugees-portraits/; the Joint Council for the Welfare of Immigrants' 'I am an immigrant' campaign, available at www.iamanimmigrant.net/i-am-immigrantposter-campaign; IOM's 'I am a migrant' project, available at http://iamamigrant. org (all accessed 11 September 2019).

4 The full collection of photographs from the Arrivals exhibition can be viewed at www.jeremyabrahams.co.uk/arrivals_sheffield (accessed 17 September 2019). I would like to take this opportunity to thank the artist Jeremy Abrahams for taking the time to speak to me about the project and for sharing his images in the spirit of productive engagement and critique. 